\title{
Antioxidants and sensory properties of the infusions of wild passiflora from Brazilian savannah: potential as functional beverages
}

\author{
Lívia de L de O Pineli, ${ }^{a *}$ Juliana da S Q Rodrigues, ${ }^{\mathrm{b}}$ Ana M Costa, ${ }^{\mathrm{C}}$ Herbert C \\ de Lima, ${ }^{c}$ Marileusa D Chiarello ${ }^{d}$ and Lauro Melo ${ }^{e}$
}

\begin{abstract}
BACKGROUND: The study of biodiversity for species recovery and sustainable use has encouraged research with plants from Brazilian savannah. We aimed to characterize chemical and sensory properties of infusions of passifloras, due to their potential as functional beverages. Infusions and hydroalcoholic extracts of four species of wild passifloras, three varieties of Passiflora edulis and a commercial passiflora tea were evaluated for total phenolics (TPs), total flavonoids (TFs), condensed tannins (CTs), and antioxidant activity (DPPH and FRAP). Free-choice Profile and acceptance, compared with green tea, were performed for sensory characterization.
\end{abstract}

RESULTS: In general, infusions had higher levels of TPs and CTs than hydroalcoholic extracts, which in turn had higher levels of TFs. Infusion of $P$. nitida showed higher amounts of TPs and antioxidant activity. Acceptance of passiflora infusions was similar or higher than that of green tea, except for $P$. alata. $P$. setacea presented a sensory profile similar to other commercial teas and higher acceptance by a group of consumers.

CONCLUSION: Passiflora infusions showed different degrees of suitability as acceptable functional beverage. Identification of phenolics and other bitter compounds is needed to understand the intense bitterness of $P$. alata, as it did not present the highest contents of TPs, CTs and TFs.

(c) 2014 Society of Chemical Industry

Supporting information may be found in the online version of this article.

Keywords: passiflora; infusions; phenolic compounds; antioxidants; sensory analysis

\section{INTRODUCTION}

Studies for the recovery of fruits from Brazilian savannah are aligned to projects such as Biodiversity for Food and Nutrition (BFN), internationally coordinated by Bioversity International and implemented by the United Nations Program for the Environment (UNEP) and the United Nations Food and Agriculture Organization (FAO), approved by the Global Environment Fund (GEF). ${ }^{1}$ These projects aim to promote the conservation and sustainable use of biodiversity in programs that contribute to the improvement of food security and human nutrition, by investigating food and nutritional properties of species related to agricultural biodiversity and by rescuing the cultural values played by many of those species. In this context, food materials rich in antioxidants and with records of popular use as functional foods have become objects of numerous studies for their chemical and nutritional characterizations. $^{2}$

The Brazilian Agricultural Research Corporation (Embrapa), unit Cerrado, is focused on research on Brazilian savannah species and has the largest passiflora collection worldwide, with over 150 accessions, including species and varieties with functional and medicinal potential. Some commercial and wild species of passiflora are already part of the global ethno-pharmacological repertoire, which recommended leaves, flowers, roots and fruits to combat many different diseases, especially those of the nervous system. ${ }^{3,4}$

* Correspondence to: Lívia de L de O Pineli, Departamento de Nutrição, Universidade de Brasília, Campus Universitário Darcy Ribeiro, Asa Norte, 70.910.900, Brasília, DF 70910900, Brazil.E-mail: liviapineli@unb.br

a Department of Nutrition, Faculty of Health Sciences, Campus Universitário Darcy Ribeiro, Universidade de Brasília, Brasília, DF 70910900, Brazil

b Human Nutrition Postgraduation Program, College of Health Sciences, Campus Universitário Darcy Ribeiro, Universidade de Brasília, Brasília, DF 70910900, Brazil

c Embrapa Cerrados, BR 020, Km 18, Laboratory of Food Science, Planaltina, Federal District, 73310970, Brazil

d Laboratory of Sensory Analysis, Catholic University of Brasilia, 71966700 Brasilia, DF, Brazil

e Department of Biochemical Engineering, School of Chemistry, Federal University of Rio de Janeiro, Rio de Janeiro, RJ 21941-909, Brazil 
Some recent studies have evaluated the levels of phenolic compounds, antioxidant activity and some health promoting effects of passiflora pulp, especially the species $P$. edulis and $P$. alata. ${ }^{5-8}$ Other studies have evaluated these properties in extracts of leaves of passiflora. ${ }^{9-12}$ However, no studies evaluating the contents of phenolic compounds in combination with the sensory properties of the products of passiflora leaves are currently reported. It is well known that polyphenolics, apart from presenting valuable biological properties, impart a high sensory activity to foods. Flavonoid phenols have been indicated as the compounds that are mainly responsible for the bitter taste and the tactile sensation of astringency in beverages such as tea, cider, and red wine. ${ }^{13}$

For commercial exploration and aiming to foster consumption of passiflora species by their functional properties, further studies on sensory characteristics of leaf infusions and their acceptance are needed. Sensory analysis generates information that cannot be obtained instrumentally. ${ }^{14}$ Descriptive studies involving chemical and sensory characteristics with the acceptance of the products are extremely useful in generating information that drives breeding and plant cultivation systems with a focus on quality optimization and increased consumption. A recent study ${ }^{15}$ demonstrated that the growth system (organic or conventional, with or without shading) has an effect on the sensory quality of nectars made with the pulp of $P$. edulis.

Therefore, we aimed to determine antioxidant properties, sensory profile and acceptance of infusions made with leaves of different passiflora acessions from Brazilian savannah, evaluating their potential as a functional beverage.

\section{EXPERIMENTAL}

The leaves of passiflora were obtained from Embrapa Cerrado. Four wild species ( $P$. alata, $P$. tenuifila, $P$. nitida and $P$. setacea) and three hybrid passionfruit varieties ( $P$. edulis Cv. BRS Ouro Vermelho, $P$. edulis cv. BRS Gigante Amarelo and $P$. edulis CV. BRS Sol do Cerrado) were studied. As a reference, a sample of commercial Passiflora spp. (useful part, stem and leaf; Santosflora Laboratory, São Paulo, SP, Brazil), bought in a popular pharmacy, was included in the experiment. Commercial green tea dried leaves were used as a sample in the acceptance test.

\section{Preparation of infusions}

Infusions were prepared at a ratio of $5 \mathrm{~g}$ of dry leaf per $1 \mathrm{~L}$ of boiling water. The concentration was previously established by a consumer focus group, where infusions with $3 \mathrm{~g} \mathrm{~L}^{-1}, 5 \mathrm{~g} \mathrm{~L}^{-1}$ or $7 \mathrm{~g} \mathrm{~L}^{-1}$ were tested. The leaves were added after water boiling temperature was achieved. The extraction lasted for $10 \mathrm{~min}$. The infusions were completed for $1 \mathrm{~L}$ with hot water.

\section{Preparation of hydroalcoholic extracts}

Preparation of the extracts was performed according to Rudnicki et al..$^{5}$ Five grams of dried leaves were mixed with $100 \mathrm{~mL}$ of aqueous ethanol $[40 \%(\mathrm{v} / \mathrm{v})]$. The extraction was carried out with an Ultraturrax homogenizer (102E) at moderate speed for 3 min and refluxed in a glycerine bath $\left(80^{\circ} \mathrm{C}\right)$ for $30 \mathrm{~min}$. The liquid was filtered under vacuum and rota-evaporated at $60^{\circ} \mathrm{C}$ for about $5 \mathrm{~min}$ and the volume was completed with methanol to $50 \mathrm{~mL}$. The sample was stored at $-80^{\circ} \mathrm{C}$.

Infusions and hydroalcoholic extracts (HAs), three replications of each treatment, were analysed for total phenolics (TPs), condensed tannins (CTs), total flavonoids (TFs) and antioxidant activity by the 2,2'-diphenyl-1-picrylhydrazyl (DPPH) and ferric reducing antioxidant power (FRAP) assays. Analyses were carried out in triplicates.

\section{Total phenolics}

TPs were quantified using a modified Folin-Ciocalteu colorimetric method. ${ }^{16} \mathrm{~A} 0.2 \mathrm{~mL}$ aliquot of the water diluted extracts was added to a $15 \mathrm{~mL}$ tube and $0.2 \mathrm{~mL}$ of 1:10 Folin-Ciocalteu reagent: water solution was added to the mixture. The tube was allowed to stand at room temperature for $1 \mathrm{~min}$. Then, $2 \mathrm{~mL}$ of $7.5 \%(\mathrm{w} / \mathrm{v})$ $\mathrm{Na}_{2} \mathrm{CO}_{3}$ were added to the mixture. After $2 \mathrm{~h}$ at room temperature, absorbance was measured at $765 \mathrm{~nm}$ versus a blank. The results were expressed as mg of gallic acid equivalent (GAE) $\mathrm{g}^{-1}$. For the hydroalcoholic extracts, dilution was carried out between 5 and $50 \mu \mathrm{L}$ of extract in $1 \mathrm{~mL}$, and for infusions, between 60 and $500 \mu \mathrm{L}$ in $1 \mathrm{~mL}$.

\section{Condensed tannins}

CTs were quantified using the vanillin method. ${ }^{17}$ Test tubes were covered with foil and added $5 \mathrm{~mL}$ of vanillin reagent $(4 \mathrm{~g}$ of pure vanillin diluted to $56 \mathrm{~mL}$ in $\mathrm{HCl}$, analytical purity, $37 \% \mathrm{w} / \mathrm{w}$, and $83 \mathrm{~mL}$ of methanol). The reactants were preheated in a water bath at $30^{\circ} \mathrm{C}$ for $30 \mathrm{~min}$. We added $1 \mathrm{~mL}$ of $\mathrm{HA}$ extract or infusion, and $5 \mathrm{~mL}$ of $72 \%$ methanol in duplicate of the 'sample blank' and $1 \mathrm{~mL}$ in the 'vanillin blank'. The reaction was kept in the water bath for $20 \mathrm{~min}$. Finally, the absorbance was measured at $510 \mathrm{~nm}$. Results were expressed as $\mathrm{mg}$ of catechin equivalent (CE) $\mathrm{g}^{-1}$.

\section{Total flavonoids}

TFs were determined according to Pereira et al. ${ }^{18}$ An aliquot of $5 \mathrm{~mL}$ was used for infusion analysis and volumes ranging from 100 to $400 \mu \mathrm{L}$ for HA extract analysis. Each sample was mixed with $500 \mu \mathrm{L}$ of methanol solution of aluminium chloride and completed to the volume of $10 \mathrm{~mL}$ with methanolic solution of acetic acid. The solution rested for $30 \mathrm{~min}$, protected from light, and absorbance was read at $425 \mathrm{~nm}$. Results were expressed in $\mathrm{mg}$ of quercetin equivalent (QE) $\mathrm{g}^{-1}$.

\section{Determination of the antioxidant activity by the DPPH assay}

Antioxidant activity was determined by the DPPH radicalscavenging method according to Rufino et al. ${ }^{19}$ Aliquots of $0.1 \mathrm{~mL}$ of the previously diluted extracts were mixed to $3.9 \mathrm{~mL}$ of $0.06 \mathrm{mmol} \mathrm{L}^{-1}$ of DPPH (initial absorbance of 0.756 ). The three dilutions applied consisted of volumes from $5 \mu \mathrm{L}$ to $350 \mu \mathrm{L}$ for $\mathrm{HA}$ extracts and from $30 \mu \mathrm{L}$ to $900 \mu \mathrm{L}$ of infusions, completed to $0.1 \mathrm{~mL}$ with methanol. The solutions were incubated at $25^{\circ} \mathrm{C}$ for $25 \mathrm{~min}$. Absorbance was recorded at $517 \mathrm{~nm}$ using methanol as blank. Total antioxidant activity was expressed as $\mathrm{EC}_{50}\left(\mathrm{~g} \mathrm{~g}^{-1} \mathrm{DPPH}\right)$.

\section{Determination of the antioxidant activity by the FRAP assay}

Antioxidant activity by FRAP assay was determined according to Rufino et al. ${ }^{20}$ A $90 \mathrm{~mL}$ aliquot of each aqueous extract dilution (from $12.5 \mathrm{mg} \mathrm{mL}^{-1}$ to $500 \mathrm{mg} \mathrm{mL}^{-1}$ for $\mathrm{HA}$ extracts and from $12.5 \mathrm{mg} \mathrm{mL}^{-1}$ to $500 \mathrm{mg} \mathrm{mL}^{-1}$ for infusions) was mixed with $270 \mathrm{~mL}$ of distilled water and $2.7 \mathrm{~mL}$ of FRAP reagent. Tubes were vortexed and incubated at $37^{\circ} \mathrm{C}$ for $30 \mathrm{~min}$. Absorbance was determined at $595 \mathrm{~nm}$ using FRAP reagent as blank and 500-2000 $\mathrm{mmol} \mathrm{L}^{-1}$ ferrous sulfate solutions substituting extracts as control. Results were expressed as $\mu$ mol ferrous sulfate $\mathrm{g}^{-1}$.

Chemical data were compared by ANOVA and when significant differences were identified we applied the Fisher test $(P<0.05)$. 


\section{Sensory evaluation}

Infusions at a concentration of $5 \mathrm{~g} \mathrm{~L}^{-1}$ were established by the focus group qualitative method, ${ }^{14}$ with 10 tea consumers, who also chose, as the best method of consumption, sugar-free iced infusions, due to the healthy characteristic that is expected for a functional beverage.

\section{Descriptive profile}

Sensory profile was assessed by the Free-choice Profile method. ${ }^{21}$ The method was chosen to eliminate training, calibration and validation phases, which involve a large number of sessions for sensory evaluation and require a large number of samples. Seasonality and low availability act as limitation factors, once wild varieties and species are not commercially available, existing only in experimental fields.

Authorization for research involving human subjects, including written informed consent of panel participants, was previously obtained from the Ethical Commission of the Faculty of Health Sciences (CEP FS/UnB Number191/11).

\section{Recruitment of the panelists}

Assessors were recruited from students, staff and professors of the Catholic University of Brasilia (UCB). For the selection of panelists, a sequence of 12 triangular tests was applied comparing two infusions of $P$. edulis. BRS Sol do Cerrado sweetened with a difference of $0.8 \%$ in relation to sucrose content. This difference was previously verified by one triangular test ( $n=30$ panelists), and concluded as significant $(P<0.05)$. Panelists who correctly marked at least $60 \%$ of the tests were approved. ${ }^{22}$

\section{Lexicon development and individual sensory scale definition} Kelly's Repertory Grid Method. ${ }^{23}$ was used to develop the list of descriptive terms to be employed by panelists for sample evaluation. All the combinations of pairs of samples were presented to panelists, individually, and they were asked to find as many differences and similarities among infusions as possible, in two sessions of evaluation. Once the list of terms had been developed, each term was located on a $9 \mathrm{~cm}$ line scale marked with the anchors $1=$ 'null or very slight' to $9=$ 'very intense'. In this way, individual score sheets were defined.

\section{Sample evaluation}

All samples were evaluated in a sequential monadic way, in two sessions. All samples were coded with three-digit numbers and presented at $9 \pm 1{ }^{\circ} \mathrm{C}$, in complete randomized design, with two replications for each treatment. Data were analyzed by generalized procrustes analysis (GPA), with Euclidean transformations of data by rotation, translation and self-scaling, followed by principal component analysis (PCA) of the consensus configuration $(P<0.05)$.

\section{Acceptance}

Students, professors and staff of UCB $(n=100)$, consumers of teas, at least twice a month, were selected. Samples were analyzed monadically in a randomized complete bock design, ${ }^{14}$ with a nine-point hedonic scale. Cluster analysis was run for a careful assessment of consumer preference. The dissimilarity coefficient used was Euclidean distance and to perform clustering, the Ward method, and automatic truncation. After clustering, means were subjected to ANOVA and to the Fisher test $(P<0.05)$. Green tea was also evaluated for a reference of acceptance. Statistical analyses were performed using XLSTAT 2011 program (Addinsoft, Paris, France).

\section{RESULTS AND DISCUSSION}

\section{Chemical characterization}

Infusions presented higher contents of TP than HA extracts, except for P. nitida (Table 1). Higher water extraction of TPs was also found by Bastos et al. working with yerba mate (Ilex paraguariensis) and green tea (Camelia sinensis) extracts. ${ }^{24}$ Wild passifloras presented equal or higher amounts of TPs than the commercial species of Passiflora edulis. For infusions and HA extracts, the descending order of TP content was: $P$. nitida $>$ P. setacea $>$ P. tenuifila $>$ P. edulis 'Gigante Amarelo', P. edulis 'Sol do Cerrado', P. alata $\geq$ P. edulis 'Ouro Vermelho' > Passiflora ssp. Silva et al. ${ }^{10}$ found a content of $8.3 \mathrm{mg}$ GAE g ${ }^{-1}$ of TPs in the infusion of leaves of Passiflora edulis grown in Campinas, São Paulo, Brazil, closer to the lowest content found in this work, for Passiflora ssp. Colomeu et al. ${ }^{9}$ found lower values for aqueous ( $9.5 \mathrm{mg} \mathrm{GAE} \mathrm{g}^{-1}$ ) and methanolic (4.9 $\mathrm{mg} \mathrm{GAE} \mathrm{g}^{-1}$ ) extracts of Passiflora alata Curtis, also grown in Campinas. It is interesting to notice that one serving $(200 \mathrm{~mL})$ of $P$. nitida infusion showed $43.60 \pm 0.50 \mathrm{mg}$ of TPs, a level comparable with $40 \mathrm{~mL}$ of Moscatel wine studied by Silva et al. ${ }^{25}$ indicating the potential of passiflora infusions as non-alcoholic functional beverages.

Unlike TPs, the extraction of TFs was higher in HA extracts, except for $P$. edulis 'Sol do Cerrado', $P$. edulis 'Ouro Vermelho' and Passiflora ssp. For HA extracts, wild passiflora exceeded the levels found in the extracts of $P$. edulis and Passiflora ssp. The descending order was $P$. nitida, $P$. alata, $P$. tenuifila, $P$. setacea $>$ $P$. edulis 'Gigante Amarelo' $\geq P$. edulis Ouro Vermelho $\geq P$. edulis 'Sol do Cerrado' $>$ Passiflora ssp. We found low discrimination among the passiflora infusions for flavonoids, except for the lower content observed for Passiflora ssp. The concentrations of TFs of passiflora infusions were close to those found for four brands of green tea and three brands of black tea in the study by Pereira et al. ${ }^{18}$

CT contents were also higher in the infusions and in wild passifloras, presenting the following descending order: $P$. nitida $>$ $P$. alata $\geq P$. tenuifila $\geq P$. setacea $\geq P$. edulis 'Gigante Amarelo' $\geq$ P. edulis 'Sol do Cerrado' $\geq$ Passiflora ssp. $\geq$ P. edulis 'Ouro Vermelho'. Infusion of $P$. nitida showed higher contents of CT $(17.81 \pm 0.61 \mathrm{mg}$ $\left(\mathrm{C} \mathrm{g}^{-1}\right)$, compared with green tea, black tea and white tea, which presented, respectively, $12.52,6.63$ and $1.43 \mathrm{mg} \mathrm{CE} \mathrm{g}^{-1}$, in the study by Jacques et al. ${ }^{26}$ The remaining infusions showed much lower values, between 0.2 and $1.5 \mathrm{mg} \mathrm{CE} \mathrm{g}^{-1}$.

The antioxidant capacity of passiflora extracts was mainly associated with the results of TPs and CTs and was higher for most infusions. The order of antioxidant activity for both extracts and for both methods was the same, with changes in significant differences among accessions. Analyzing infusions, the decreasing order of antioxidant activity by the FRAP assay was $P$. nitida $>$ $P$. tenuifila $>P$. setacea $\geq P$. edulis 'Gigante Amarelo' $\geq P$. edulis 'Sol do Cerrado', P. alata, P. edulis 'Ouro Vermelho' $\geq$ Passiflora spp.

The structural diversity of phenolic compounds interfere in their physico-chemical behavior (solubility, partition coefficient, ionization constant), which may explain the different results found for antioxidant variables in infusions and HA extracts. ${ }^{27}$

Our results suggest a higher antioxidant activity of passiflora infusions than that of berries, well known as rich in antioxidants. Souza et al. ${ }^{28}$ determined antioxidant activity of Brazilian blackberry, red raspberry, strawberry, blueberry and sweet cherry fruits and found values between $2140 \mathrm{~g} \mathrm{~g}^{-1} \mathrm{DPPH}$ (blackberry) and $7775 \mathrm{~g} \mathrm{~g}^{-1}$ DPPH (blueberry). In our work, passiflora infusions 
presented values varying from $472.53 \pm 61.00 \mathrm{~g} \mathrm{~g}^{-1} \mathrm{DPPH}$ to $2219.87 \pm 92.90 \mathrm{~g} \mathrm{~g}^{-1} \mathrm{DPPH}$, indicating higher antioxidant capacities. Regarding the RAP assay, the antioxidant activity found for $P$. nitida infusion $\left(589.65 \pm 14.39 \mu \mathrm{mol}\right.$ ferrous sulfate $\left.\mathrm{g}^{-1}\right)$ was about 17-fold the antioxidant activity of strawberries, a well-known source of phenolic compounds. ${ }^{29}$

The main groups of polyphenols are defined according to their carbon skeleton. From a sensory point of view, larger molecules tend to be less bitter and more astringent. ${ }^{13}$ Besides their antioxidant capacity, phenolic compounds have attracted considerable interest because of their influence on sensory characteristics such as color, bitterness and astringency and in formation of certain flavors. Only in studies with wines are such assessments more exploited. ${ }^{30}$

\section{Sensory profile}

According to selection criteria and evaluation of the residual variance of each panelist from GPA, we selected nine assessors. Attributes raised by the panel are shown in Table 2, as well as their descriptions and identifications of panelists.

In relation to appearance, all panelists indicated the same attributes, which were yellow color and translucency. Regarding odor, only sweet odor was mentioned by all panelists. Earthy odor, odor of green fruit, artificial odor of passion fruit and odor of flowers were cited by one assessor each. Bitterness was the flavor attribute cited by all panelists. Sweetness was cited by six panelists. Flavor of gilo (Solanum gilo), flavor of green fruit and flavor of the infusion of passion fruit leaf had one mention each.

According to the overlap of each attribute (Fig. 1), high consensus was observed for bitterness, yellow color and translucency. Sweet odor and odor of honey also showed a quite significant consensus and it is still possible to see a positive association between these attributes. Lack of consensus was visible for sweetness, which may indicate that other attributes are confounding panelists for their quantification, possibly bitterness.

PCA (Fig. 2a and b) of the consensus configuration presented $75.45 \%$ of explanation for D1 (55.27\%) and D2 (20.18), and showed the formation of three distinct groups of samples. Sufficiently far from the other samples, P. alata appeared in the first quadrant, positively correlated with the attributes bitterness, flavor of green tea, flavor of gilo and, as a contradiction between tastes and odors, the odor of honey and sweet odor, as indicated by the proximity of the sample to those attributes.

$P$. setacea, also separated from the others, was strongly characterized by the attributes odor and flavor of black tea, odor of yerba mate tea and yellow color, indicating a higher sensory similarity with other commercial teas consumed on a large scale.

The remaining samples were very close together, which suggests similar sensory profiles. For these samples, the attributes that stood out were: sweetness, odor of green leaf, earthy odor, odor of flowers and translucency.

According to chemical analysis, the infusion with higher amounts of TP and condensed tannins was P. nitida (Table 1). However, that infusion was not superior for bitterness nor astringency, whose closest attribute, among the reported ones, was 'flavor of green fruit'. We believe that the phenolic profile of $P$. alata or the presence of other bitter compounds may provide explanation for their sensory differentiation from other infusions, with rather sharp bitterness (Fig. 2), although this infusion did not show a high amount of TP (Table 1).

For astringency, the molecular weight seems to be important for its perception and the interactions of tannins with salivary proteins 
Table 2. Attributes raised by the panelists with their respective description and identification

\begin{tabular}{|c|c|c|}
\hline Attribute & Description & Panelists \\
\hline \multicolumn{3}{|l|}{ Appearance } \\
\hline Yellow color & Intensity of yellow color & $A, B, C, D, E, F, G, H, I$ \\
\hline Translucent & Easy passage of light by the liquid & $A, B, C, D, E, F, G, H, I$ \\
\hline \multicolumn{3}{|l|}{ Odor } \\
\hline Sweet odor & Refers to sweet odor & $A, B, C, D, E, F, G, H, I$ \\
\hline Artificial odor of passion fruit & Characteristic odor of unnatural passion fruit & A \\
\hline Earthy odor & Refers to characteristic wet earthy odor & G \\
\hline Odor of leaf & Characteristic odor of leaf & $B, D, F, I$ \\
\hline Odor of black tea & Characteristic odor of black tea & $A, D, E, F, G$ \\
\hline Odor of honey & Characteristic odor of natural honey & $A, B, G$ \\
\hline Odor of green fruit & Fruit flavor that have not matured & G \\
\hline Odor of yerba mate tea & Characteristic odor of yerba mate tea & $C, 1$ \\
\hline Odor of flowers & Odor of citric flowers & $\mathrm{E}$ \\
\hline Odor of dry leaf of passion fruit & Odor of sun-dried passion fruit leaf & $C, D, I$ \\
\hline \multicolumn{3}{|l|}{ Flavor } \\
\hline Bitterness & Refers to bitter taste & $A, B, C, D, E, F, G, H, I$ \\
\hline Sweetness & Refers to sweet taste & $A, C, D, F, G, I$ \\
\hline Flavor of gilo & Bitter taste that remind flavor of gilo & $\mathrm{F}$ \\
\hline Flavor of green fruit & Flavor of something astringent & $\mathrm{F}$ \\
\hline Flavor of green tea & Flavor that reminds taste of green tea & $\mathrm{B}, \mathrm{C}, \mathrm{D}, \mathrm{H}$ \\
\hline Flavor of black tea & Characteristic flavor of black tea & $B, C, D, G, H$ \\
\hline Flavor of yerba mate tea & Characteristic flavor of yerba mate tea & $\mathrm{C}, \mathrm{F}$ \\
\hline Flavor of tea of passion fruit & Characteristic flavor of tea of passion fruit homemade & I \\
\hline
\end{tabular}

\section{Dimensions (axes F1 e F2: $75.45 \%$ )}

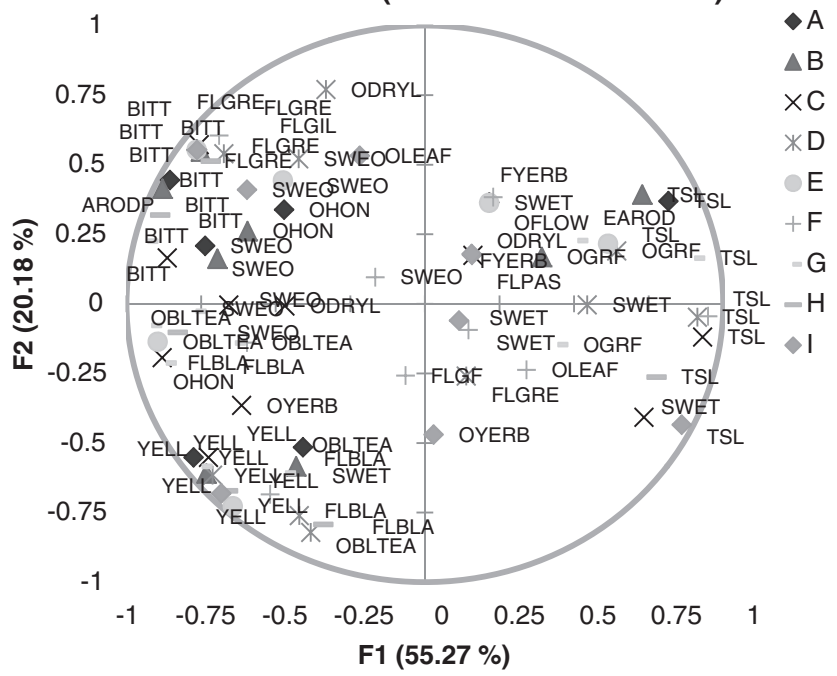

Figure 1. Overlapping of individual and consensus configurations (panelists A-I). Attributes are: YELL, yellow color; TSL, translucency; SWEO, sweet odor; ARODP, artificial odor of passion fruit; EAROD, earthy odor; OLEAF, odor of leaf; OBLTEA, odor of black tea; OHON, odor of honey; OGRF, odor of green fruit; OYERB, odor of yerba mate tea; OFLOW, odor of flower; ODRYL, odor of dry leaf of passion fruit; BITT, bitterness; SWET, sweetness; FLGIL, flavor of gilo; FLGF, flavor of green fruit; FLGRE, flavor of green tea; FLBLA, flavor of black tea; FYERB, flavor of yerba mate tea; FLPAS, flavor of tea of passion fruit.

result in the perception of astringency. ${ }^{31}$ In the method of vanillin to determine condensed tannins, both the leuco-anthocyanidins (catechins) and pro-anthocyanidins (condensed tannins) react with vanillin in the presence of $\mathrm{HCl}$ to produce a red condensation product, which is detected spectrophotometrically. ${ }^{17}$ Despite the high concentration of tannins in P. nitida, the degree of condensation cannot be known by this method. The high value of condensed tannins could be related to the presence of catechins and/or tannins with low degree of polymerization, which does not affect strongly astringency. In fact, the 'flavor of green fruit' attribute is located near the origin (Fig.2), indicating the low importance of this characteristic in discriminating the samples.

\section{Acceptance}

The results of acceptance were subjected to cluster analysis resulting in two groups of consumers, with 60 and 40 panelists (Table 3). In general, passiflora infusions were more accepted than green tea, except for the infusion of $P$. alata, the least accepted among all samples.

From the segmentation of consumers, it was observed that the means of acceptance of the Cluster 1 were significantly higher than those of Cluster 2. For Cluster 1, the acceptance of $P$. setacea was statistically higher than that of Passiflora spp. and green tea. The other samples showed intermediate acceptances. For Cluster 2 , there was higher acceptance for P. nitida, Passiflora spp., and $P$. edulis of the three cultivars. The acceptance of $P$. nitida was significantly higher than that of $P$. setacea and $P$. tenuifila, which were in turn more acceptable than green tea and $P$. alata.

Despite the option of the focus group by the sensory analysis of unsweetened iced teas, the lack of sugar in the infusions may be one strong cause for not so high acceptance means, as we observed. Commercial iced teas are sweetened with sugar or sweeteners. People who consume unsweetened teas are a small and specific group of consumers. Further studies could be recommended with sweetened infusions. Many discussions regarding health, however, are the backdrop for the development of this product, since sugar sweetened teas have a high glycemic 

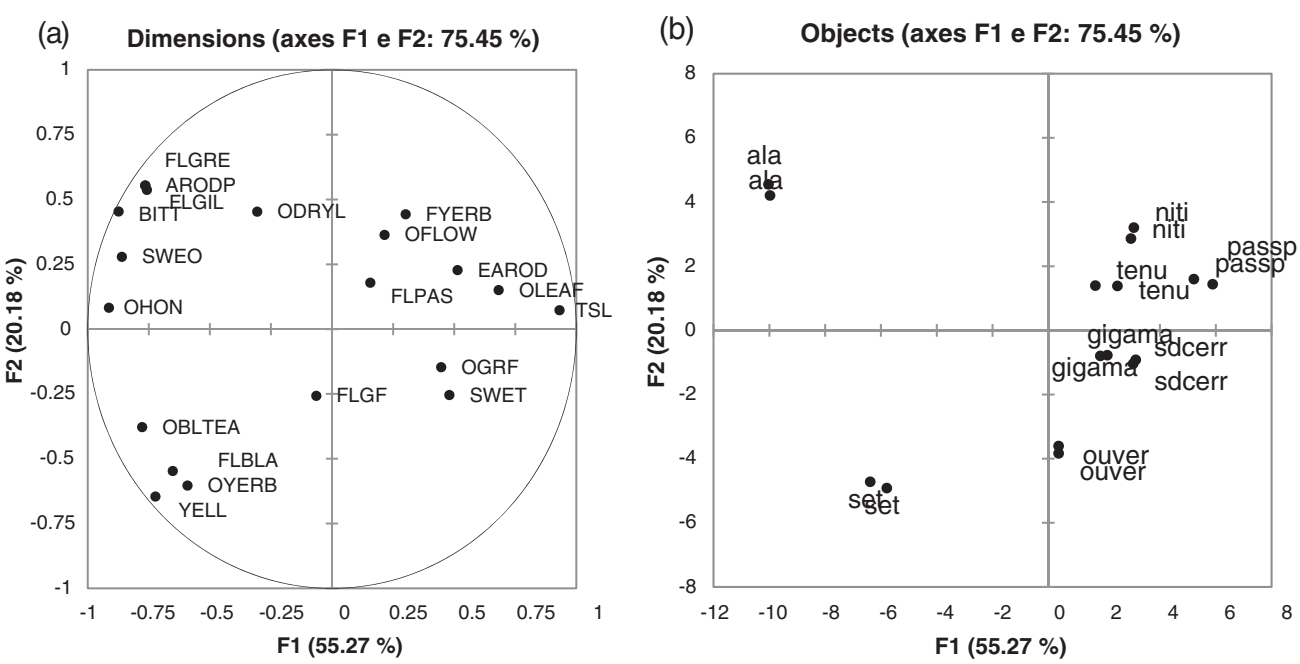

Figure 2. Principal component analysis (PCA) of the data generated by free profile factorial plan (D1 $\times D 2)$. (a) Configuration of the observations; (b) configuration of the variables. The attributes are as in Fig. 1. The variables are: P. nitida (niti), P. alata (ala); P. tenuifila (tenu); P. setacea (set); P. edulis 'Gigante Amarelo' (gigama), P. edulis 'Sol do Cerrado (sdcerr); P. edulis 'Ouro Vermelho (ouver); Passiflora ssp. (passp).

\begin{tabular}{|c|c|c|c|}
\hline Class & Cluster $1(n=40)$ & Cluster $2(n=60)$ & Total \\
\hline P. nitida & $5.875^{\mathrm{aAB}} \pm 1.65$ & $4.50^{\mathrm{bA}} \pm 1.95$ & $5.05^{\mathrm{A}} \pm 1.95$ \\
\hline P. alata & $2.80^{\mathrm{aC}} \pm 2.02$ & $1.80^{\mathrm{bD}} \pm 1.38$ & $2.20^{C} \pm 1.72$ \\
\hline P. tenuifila & $5.95^{\mathrm{aAB}} \pm 1.65$ & $3.57^{b C} \pm 2.03$ & $4.52^{A} \pm 2.21$ \\
\hline P. setacea & $6.23^{\mathrm{aA}} \pm 1.37$ & $3.77^{\mathrm{bBC}} \pm 1.97$ & $4.75^{A} \pm 2.12$ \\
\hline $\begin{array}{l}\text { P. edulis 'G. } \\
\text { Amarelo' }\end{array}$ & $5.80^{\mathrm{aAB}} \pm 1.50$ & $3.98^{\mathrm{bABC}} \pm 1.80$ & $4.71^{\mathrm{A}} \pm 1.89$ \\
\hline $\begin{array}{l}\text { P. edulis 'S. do } \\
\text { cerrado' }\end{array}$ & $6.05^{\mathrm{aAB}} \pm 1.52$ & $4.25^{\mathrm{bAB}} \pm 1.64$ & $4.97^{\mathrm{A}} \pm 1.81$ \\
\hline $\begin{array}{l}\text { P. edulis 'O. } \\
\text { vermelho' }\end{array}$ & $5.98^{\mathrm{aAB}} \pm 1.51$ & $4.03^{\mathrm{bABC}} \pm 1.79$ & $4.81^{A} \pm 1.93$ \\
\hline Passiflora ssp. & $5.35^{\mathrm{aB}} \pm 2.00$ & $3.97^{\mathrm{bAB}} \mathrm{C} \pm 2.20$ & $4.52^{A} \pm 2.20$ \\
\hline Green tea & $5.45^{\mathrm{aB}} \pm 1.83$ & $2.17^{\mathrm{bD}} \pm 1.32$ & $3.48^{B} \pm 2.22$ \\
\hline
\end{tabular}

Means followed by the same lowercase letters in the same row (just between cluster 1 and cluster 2 ) do not differ according to the $t$ test $(P \leq 0.05)$.

Means followed by the same uppercase letters in the same column (within each cluster) do not differ according to the Fisher test $(P \leq 0.05)$.

index. ${ }^{32}$ The addition of synthetic sweeteners could be contradictory to consumers that seek to use those teas as functional beverages. Furthermore, studies indicate that the application of the natural stevia-based sweetener implies intense bitter aftertaste, which could increase the rejection of the product. ${ }^{33}$ Studies show that one mechanism for increasing the liking of food is the provision of information reporting the health benefits. ${ }^{34-36}$ Cox et al. ${ }^{34}$ found that health information influenced positively acceptance responses of Brussels sprouts. Similarly, Sabbe et al. ${ }^{36}$ observed a positive effect of health information about acai (Euterpe oleracea) juices on hedonic and sensory measures, as well as on health and nutrition-related attribute perceptions and purchase intention.

\section{CONCLUSIONS}

The infusion of $P$. nitida stood out from a chemical point of view, presenting relevant amounts of phenolics and high antioxidant activity. It was also preferred by one group of consumers. From a sensory point of view, infusion of $P$. alata was less accepted. Iced infusions of passiflora were equally or more accepted than iced green tea, except for $P$. alata in Cluster 1, suggesting that these drinks have sensory potential to be consumed as a functional beverage, like green tea. Bitterness was the attribute most positively associated with P. alata and may be possibly the driver of dislike of these iced infusions. P. setacea, with higher acceptance for Cluster 1, already stood out for greater sensory similarity to other commercial teas consumed on a large scale. Further studies are suggested for the identification of phenolic and other bitter compounds present in infusions of passiflora from Brazilian savannah, in order to assign specific structures, probably in higher concentrations in P. alata, and responsible for its higher bitterness, since this sample showed no highlight in terms of TP, condensed tannins and total flavonoids. It was concluded that passiflora infusions showed different degrees of suitability as functional beverage and have potential for the development of other form of consumption, beyond the passiflora fruits. Consumption and increased acceptance may be stimulated by disseminating information about their levels of antioxidants and the discovery of new properties, as researches to evaluate existing claims from popular use are carried out.

\section{ACKNOWLEDGEMENTS}

We acknowledge Agreement Embrapa-Monsanto and CNPq for financial support and CAPES for scholarship support.

\section{SUPPORTING INFORMATION}

Supporting information may be found in the online version of this article.

\section{REFERENCES}

1 Ministry of Environment, Biodiversity for Food and Nutrition, Brazil (2012). Available: http://www.mma.gov.br/biodiversidade/ conserva\%C3\%A7\%C3\%A3o-e-promo\%C3\%A7\%C3\%A3o-do-usoda-diversidade-gen\%C3\%A9tica/biodiversidade-para-alimenta\% C3\%A7\%C3\%A3o-e-nutri\%C3\%A7\%C3\%A3o. [19 November 2013]. 
2 Zeraik ML, Pereira CAM, Zuin VG and Yariwaki JH, Passion fruit: A functional food? Rev Bras Farmagnosia 20:459-471 (2010).

3 Dhawan K, Dhawan S and Sharma A, Passiflora: A review update. J Ethnopharmacol 94:1-23 (2004).

4 Costa AM and Tupinambá DD, O maracujá e suas propriedades medicinais - estado da arte, in Maracujá: Germoplasma e Melhoramento Genético, ed. by Faleiro FG, Junqueira NTV and Braga MF. Planaltina, Embrapa Cerrados, pp. 475-506 (2005).

5 Rudnicki M, Oliveira MR, Pereira TV, Reginatto FH, Dal-Pizzol F and Moreira JCF, Antioxidant and antiglycation properties of Passiflora alata and Passiflora edulis extracts. Food Chem 100:719-724 (2007).

6 Zeraik ML, Serteyn D, Deby-Dupont G, Wauters JN, Tits M, Yariwake JH, et al., Evaluation of the antioxidant activity of passion fruit (Passiflora edulis and Passiflora alata) extracts on stimulated neutrophils and myeloperoxidase activity assays. Food Chem 128:259-265 (2011).

7 Rudnicki M, Silveira MM, Pereira TV, Oliveira MR, Reginatto FH, Dal-Pizzol F, et al., Protective effects of Passiflora alata extract pretreatment on carbon tetrachloride induced oxidative damage in rats. Food Chem Toxicol 45:656-661 (2007).

8 Zeraik ML and Yariwake $\mathrm{JH}$, Quantification of isoorientin and total flavonoids in Passiflora edulis fruit pulp by HPLC-UV/DAD. Microchem J 96:86-91(2010)

9 Colomeu TC, Figueiredo D, Cazarinb CCB, Schumacher NSG, Maróstica Jr MR, Meletti LMM, et al., Antioxidant and anti-diabetic potential of Passiflora alata Curtis aqueous leaves extract in type 1 diabetes mellitus (NOD-mice). Int Immunopharmacol 18:106-115 (2014).

10 Silva JK, Cazarin CBB, Colomeu TC, Batista AG, Meletti LMM, Paschoal JAR, et al., Antioxidant activity of aqueous extract of passion fruit (Passiflora edulis) leaves: in vitro and in vivo study. Food Res Int 53:882-890 (2013).

11 Muller SD, Vasconcelos SB, Coelho M and Biavatti MW, LC and UV determination of flavonoids from Passiflora alata medicinal extracts and leaves. J Pharmacol Biomed Anal 37:399-403 (2005).

12 Doyama JT, Rodrigues HG, Novelli ELB, Cereda E and Vilegas W, Chemical investigation and effects of the tea of Passiflora alata on biochemical parameters in rats. J Ethnopharmacol 96:371-374 (2005).

13 Lesschaeve I and Noble AC, Polyphenols: Factors influencing their sensory properties and their effects on food and beverage preferences. Am J Clin Nutr 81:330S-335S (2005).

14 Minim VPR, Análise Sensorial Estudos com Consumidores. UFV ed. by Viçosa, pp. 65-82 (2006).

15 Rodrigues JSQ, Pineli LLO, Rodrigues NG, Lima HC, Costa AM, Silva CHO, et al., Sensory analysis of nectar of passion fruit cv. BRS Ouro Vermelho under different crop systems. Rev Ceres 60:592-602 (2013).

16 Singleton VL, Orthofer R and Lamuela-Raventos RM, Analysis of total phenols and other oxidation substrates and antioxidants by means of Folin-Ciocalteu reagent. Methods Enzymol 299:152-178 (1999).

17 Broadhurst RB and Jones WTJ, Analysis of condensed tannins using acidified vanillin. J Sci Food Agric 29:788-794 (1978).

18 Pereira AV, Almeira TC, Beltrame FL, Costa ME and Garrido LH, Determinação de compostos fenólicos em amostras comerciais de chá verde e preto - Camelia sinensis (L.) Kuntze, Theaceae. Acta Sci Health Sci 31:119-124 (2009).

19 Rufino MSM, Alves RE, Brito ES, Morais SM, Sampaio CG, Jimezes-Perez J, et al., Metodologia Científica: Determinação da Atividade Antioxidante Total pela Captura do Radical Livre DPPH. (2007). Available: http://www.cnpat.embrapa.br/cnpat/down/index.php?pub/ Cot_127.pdf [03 November 2008].
20 Rufino MSM, Alves RE, Brito ES, Morais SM, Sampaio CG, Jimezes-Perez J, et al., Metodologia Científica: Determinação da Atividade Antioxidante Total em Frutas pelo Método de Redução de Ferro (FRAP). (2006). Available: http://www.cnpat.embrapa.br/cnpat/ down/index.php?pub/cot_125.pdf [03 November 2008]

21 Williams AA and Arnold GM, A comparison of the aromas of six coffees characteristics by conventional profiling, free-choice profiling and similarity scaling methods. J Sci Food Agric 36:204-214 (1985).

22 Verruma-Bernardi MR and Damásio MH, Free choice profile descriptive analysis of mozzarella cheese from buffalo milk. Food Sci Technol Brazil 24:536-542 (2004).

23 Moskowitz HR. Product Testing and Sensory Evaluation of Foods. Food and Nutrition Press, Westport (1983).

24 Bastos DHM, Saldanha LA, Catharino RR, Sawaya ACHF, Cunha IBS, Carvalho PO, et al., Phenolic antioxidants identified by ESI-MS from yerba mate (Ilex paraguariensis) and green tea (Camelia sinensis) extracts. Molecules 12:423-432 (2007).

25 Silva SD, Feliciano RP, Boas LV and Bronze MR. Application of FTIR-ATR to Moscatel dessert wines for prediction of total phenolic and flavonoid contents and antioxidant capacity. Food Chem 150:489-493 (2014).

26 Jacques AC, Chim JF, Zambiazi RC, Gandra EA, Alicieo TVR, Machado MRG, et al., Contents of Condensed Tannins in Commercial Tea of Camelia sinensis. [Online] (2010). Available: http://www2. ufpel.edu.br/cic/2010/cd/pdf/CA/CA_00628.pdf. [02 May 2014].

27 Naczk M and Shahidi F, Extraction and analysis of phenolics in food. J Chromatogr A 1054:95-111 (2004).

28 Souza VR, Pereira PAP, Silva TLT, Lima LC and Queiroz F, Determination of the bioactive compounds, antioxidant activity and chemical composition of Brazilian blackberry, red raspberry, strawberry, blueberry and sweet cherry fruits. Food Chem 156:362-368 (2014).

29 Pineli LLO, Moretti CL, Santos MS, Campos AB, Brasileiro AV, Córdova $A C$, et al., Antioxidants and other chemical and physical characteristics of two strawberry cultivars at different ripeness stages. J Food Compos Anal 24:11-16 (2011).

30 Manfroi V, Costa GP, Guerra CC, Zanus MC, Fialho FB and Rombaldi CV, Application of enological tannins in the development of Cabernet Sauvignon and their effects on the sensory quality. Ciência Rural 40:175-181 (2010).

31 El Gharras H, Polyphenols: food sources, properties and applications - A review. Int J Food Sci Technol 44:2512-2518 (2009).

32 Guerreiro S, Alçada M and Azevedo I, Sugary drinks and glycemia. Acta Med Portug 23:567-578 (2010).

33 Cardello MAB, Silva MAAP and Damasio MH, Time-intensity of sweet and bitter taste of stevia leaves (Stevia rebaudiana Bertoni) extract in equi-sweet on sucrose. Food Sci Technol Brazil 19:163-169 (1999).

34 Cox DN, Melo L, Zabaras D and Delahunty CM, Acceptance of health-promoting Brassica vegetables: the influence of taste perception, information and attitudes. Public Health Nutr 15:1474-1482 (2012).

35 Eertmans E, Baeyens $\mathrm{F}$ and van den Bergh O, Food likes and their relative importance in human eating behavior: Review and preliminary suggestions for health promotion. Health Educ Res 16:443-456 (2001).

36 Sabbe S, Verbeke W, Deliza R, Matta V and Van Damme P, Effect of a health claim and personal characteristics on consumer acceptance of fruit juices with different concentrations of acai (Euterpe oleracea Mart.). Appetite 53:84-92 (2009). 